\title{
THE IMPACT OF NONINVASIVE VENTILATION DURING THE PHYSICAL TRAINING IN PATIENTS WITH MODERATE-TO-SEVERE CHRONIC OBSTRUCTIVE PULMONARY DISEASE (COPD)
}

\author{
Andreza Toledo, Audrey Borghi-Silva, Luciana Maria Malosá Sampaio, Karla \\ Paiva Ribeiro, Vilmar Baldissera, Dirceu Costa
}

Toledo A, Borghi-Silva A, Sampaio LMM, Ribeiro KP, Baldissera V, Costa D. The impact of non-invasive ventilation during the physical training in patients with moderate-to-severe chronic obstructive pulmonary disease (COPD). Clinics. 2007;62(2):113-20.

OBJECTIVE: To evaluate the influence of physical training with or without noninvasive ventilation at 2 levels of pressure in the airways $\left(\right.$ BiPAP $\left.^{\circledR}\right)$ in patients with chronic obstructive pulmonary disease.

METHODS: Eighteen patients with $\mathrm{FEV}_{1}=34 \pm 8 \%$ of predicted values, mean age of $68 \pm 9$ years were randomly distributed into 2 groups, one group performing physical training on a treadmill and the other group performing physical training associated with BiPAP ${ }^{\circledR}$ (physical training+B), for 30 minutes, 3 times a week for 12 weeks. The training velocity was based on a test of cardiopulmonary force performed pre- and postintervention, which registered the values for heart rate, systolic blood pressure, diastolic blood pressure, peripheral oxygen saturation, blood lactate, sensation of dyspnea, respiratory muscle strength, and analysis of gases expired such as oxygen consumption and the production of carbon dioxide.

RESULTS: For both groups, there was a significant improvement in dyspnea and peripheral oxygen saturation at identical levels of physical exercise, in distance walked during the physical training, and in respiratory muscle strength $(P<0.05)$. Only the physical training+B group had a significant improvement in heart rate, systolic blood pressure, and oxygen consumption after training $(P<0.05)$. Significant reductions of blood lactate were observed at identical levels of exercise in physical training $+\mathrm{B}$ when compared to isolated physical training (from $1.3 \pm 0.7 \mathrm{mMol} / \mathrm{L}$ versus $2.5 \pm 0.9 \mathrm{mMol} / \mathrm{L},(P<0.05)$, respectively).

CONCLUSION: Physical training associated with BiPAP ${ }^{\circledR}$ enhanced the oxidative muscular capacity and could be an adjunctive recourse for physical rehabilitation in patients with chronic obstructive pulmonary disease.

KEYWORDS: Chronic obstructive pulmonary disease (COPD). Physical training. BiPAP ${ }^{\circledR}$. Noninvasive ventilation. Cardiopulmonary test.

\section{INTRODUCTION}

Patients with chronic obstructive pulmonary disease (COPD) present a greater limitation in physical exercise due to dyspnea. ${ }^{1-3}$ Increased airway resistance, insufficient ventilation, hyperinsuflation, respiratory muscle mechanical disability, and gas exchange abnormalities associated

Federal University of São Carlos - São Carlos/SP, Brazil.

Email: andrezatoledo@aol.com

Received for publication on July 5, 2006.

Accepted for publication on November 14, 2006. with the symptoms of dyspnea contribute to the ventilatory limitation during effort in these patients. ${ }^{1,4,5}$

Physical training, in general, has the objective of improving the efficiency of the capacity of the uptake system, transport, and metabolism of oxygen ${ }^{6}$ and is essential in the treatment of patients with COPD, as its objective is to improve tolerance for physical exercise, respiratory muscle effort, and endurance as well as reduce the symptoms of dyspnea. ${ }^{7-11}$

According to Bourjeily \& Rochester, ${ }^{12}$ physical training should have a duration of 6 to 12 weeks at a frequency 
of 3 times per week. Some studies have demonstrated that 6 weeks of physical training can provide an increased functional capacity for these patients, ${ }^{7,9,13}$ although the short period of physical training may be a limiting factor ${ }^{12}$ for serious cases. In patients with greater functional limitations, the use of noninvasive ventilation (NIV) at 2 pressure levels $\left(\right.$ BiPAP $\left.^{\circledR}\right)$ used as an adjunct to physical training has been studied in patients with COPD. It is believed that positive pressure is available during the auxiliary inspiratory phase of ventilation in the patient and reduces the work of the respiratory musculature, diminishing the intrinsic positive end expiratory pressure (PEEPi) through the constant application of expiratory support. ${ }^{14-17}$

Costes et $\mathrm{al}^{18}$ conducted a physical training program using an ergometric bicycle for 8 weeks associated with NIV $\left(\right.$ BiPAP $\left.^{\circledR}\right)$ and observed a significant increase in the oxygen consumption $\left(\mathrm{VO}_{2}\right)$ compared to physical training alone. However, Bianchi et $\mathrm{al}^{19}$ did not find additional effects from proportional assisted ventilation support when associated with a physical training program for patients with COPD.

We hypothesized that physical training on a treadmill with BiPAP compared to physical training without BiPAP would improve the respiratory variables in moderate/severe COPD.

\section{MATERIALS AND METHODS}

\section{Subjects}

Eighteen individuals of both sexes were referred to the Respiratory Physical Therapy Service at the Federal University of São Carlos (UFSCar) between February and December 2004 by medical prescription with a clinical and spirometric diagnosis of COPD. The patients underwent a general evaluation and specific respiratory system testing of pulmonary function (spirometry) using a portable spirometer (Vitalograph, Hand Held 2021) in an acclimatized room $\left(22^{\circ} \mathrm{C}\right.$ to $\left.24^{\circ} \mathrm{C}\right)$. The technical procedures, criteria of acceptability, and reproducibility were performed according to specifications adopted by the American Thoracic Society. ${ }^{20}$ The reference values of Knudson et $\mathrm{al}^{21}$ were used.

The criteria for inclusion in the study were the following: Patients should present a forced expiratory volume on first second $\left(\mathrm{FEV}_{1}\right)<60 \%$ and $\mathrm{FEV}_{1} / \mathrm{FVC}<70 \%$ of the predicted $^{20}$ as well as should be clinically stable for a minimum period of 6 months and present no associated cardiovascular diseases, orthopedic diseases, reactive hypertension relative to effort, nor neuromuscular disorders that would impede the performance of the experimental procedures in this study.
After having the objectives and procedures that would be performed explained to them, patients signed a Term of Consent for participation in the proposed program in accordance with the recommendations of Resolution 196/96 of the National Health Council of Brazil. This study was approved by the Committee for Ethical Research on $\mathrm{Hu}$ man Beings of the institution.

\section{Experimental Design}

Before and after the treatment, patients underwent the following evaluations:

Respiratory Muscle Strength. Respiratory muscle strength was obtained using an analogic manovacumeter with a $\mathrm{cm} \mathrm{H}_{2} \mathrm{O}$ scale, (Ger-ar; SP, Brasil). Maximal inspiratory pressure (PImax) and maximal expiratory pressure (PEmax) were measured according to the method described by Black and Hyatt, ${ }^{22}$ in which the individual uses a nose clip while remaining in an orthostatic position. PImax was measured from residual volume after maximum expiration, and PEmax was measured close to total pulmonary capacity, after maximum inspiration. The individuals were instructed to maintain pressure for more than 1 second, and each maneuver was performed a minimum of 3 times, with the highest value used for the analysis. ${ }^{23}$

Cardiopulmonary Physical Testing (CPT). Cardiopulmonary physical testing (CPT) was carried out on an Inbramed Milenium treadmill model ATL (RS, Brazil) using an increasing speed protocol, beginning at $2 \mathrm{~km} / \mathrm{h}$, for 2 minutes, with increments of $0.5 \mathrm{~km} / \mathrm{h}$ at every $2 \mathrm{~min}$ utes. Continuous monitoring was done throughout the test using a Nonin 8400A pulse oximeter (Plymouth, USA) for peripheral oxygen saturation $\left(\mathrm{SpO}_{2}\right)$, heart rate $(\mathrm{HR})$ using a frequencymeter (Polar Precision Performance, Kemple, Finland), and an electrocardiogram monitor using an Ecafix TC 500 (SP, Brazil). Also were recorded were the $\mathrm{SpO}_{2}$, HR, and sensation of dyspnea using a Borg CR10 modified scale. ${ }^{24}$ The systolic blood pressure (SBP) and diastolic blood pressure (DBP) were measured on the left upper arm using an sphygmomanometer by indirect method. Blood samples were collected from the earlobe for blood lactate analysis. Blood lactate was measured at rest and every 2 minutes during the test. The interruption criteria for CPT were an intense sensation of dyspnea, arrhythmia, increase in HR above the maximum predicted for the age of the individual, or drops in $\mathrm{SpO}_{2}<80 \%$.

Blood Lactate Dosage after aseptic cleaning of the region with alcohol; a puncture in the earlobe was made with a disposable lancet. The first drop of blood was discarded to avoid contamination by lactate eliminated through sweat. Each arterial blood sample was collected in a capillary tube 
previously treated with $25 \mathrm{ml}$ of heparin. The blood was deposited into $2 \mathrm{~mL}$ Eppendorf tubes containing $50 \mathrm{ml}$ of $1 \%$ sodium fluoride as a glycolysis preservative. The blood was stored at $-10^{\circ} \mathrm{C}$ for later analysis. Blood lactate concentration was performed using a portable electrochemical lactometer (YSI model 1500 Sport lactometer, Yellow Springs Inc. USA) using the electro-enzymatic method.

Analysis of Expired Gas. Analysis of expired gas was performed using a metabolic system (MedGraphis Model $\mathrm{VO}_{2000}$, St Paul MN, USA), operated by microcomputer (Pentium II) using Aerograph software for capture and storage of signals. The $\mathrm{VO}_{2000}$ measured microsamples of expired gas at the rate of 20 in 20 seconds, and the metabolic data generated were plotted in graphs and tables. The variables analyzed were $\mathrm{VO}_{2}(\mathrm{~L} / \mathrm{min})$ and $\mathrm{VCO}_{2}(\mathrm{~L} / \mathrm{min})$, expressed at standard temperature and pressure dry (STPD).

Treatments. The patients were divided randomly into 2 groups, one undergoing physical training on a treadmill (PT) and the second undergoing PT associated with the use of bi-level NIV (PT+B), using a BiPAP ${ }^{\circledR}$ (S-Respironics Inc., Pennsylvania-USA). Through a nasal mask, inspiratory pressure levels (IPAP) between 10 and $15 \mathrm{~cm} \mathrm{H}_{2} \mathrm{O}$ and expiratory pressure levels (EPAP) between 4 and $6 \mathrm{~cm} \mathrm{H}_{2} \mathrm{O}$ were applied to the airways, adjusted in accordance with the tolerance and comfort reported by each patient. The inspiratory level was set at $5 \mathrm{~cm} \mathrm{H}_{2} \mathrm{O}$ and was increased gradually by $2 \mathrm{~cm} \mathrm{H}_{2} \mathrm{O}$ every minute to a maximum of 15 $\mathrm{cm} \mathrm{H}_{2} \mathrm{O}$. Expiratory pressure was set at $3 \mathrm{~cm} \mathrm{H}_{2} \mathrm{O}$ and was increased gradually by $1 \mathrm{~cm} \mathrm{H}_{2} \mathrm{O}$ every minute to a maximum of $6 \mathrm{~cm} \mathrm{H}_{2} \mathrm{O}$. The gradual increase in both the inspiratory and expiratory pressures was aimed at increasing comfort and compliance in volunteers. These values were set in an arbitrary manner and designed to provide what would be considered by most patients as mild expiratory pressure and moderate inspiratory pressure support.

For both groups, the protocol was administered in 30minute sessions, 3 days a week on alternate days, for 12 weeks. The intensity of the applied training corresponded to $70 \%$ of the maximum speed reached by each patient at the pretreatment CPT.

Statistical Analysis. Due to the non-normal distribution of the data, the Wilcoxon and Mann Whitney nonparametric tests were used for intragroup and intergroup comparisons, respectively, with the level of significance set at level of significance of $P$ d" 0.05 .

\section{RESULTS}

The anthropometric and demographic characteristics of the study population are presented in Table 1. All patients had moderate to severe COPD, as evidenced by reduced forced expiratory volume in 1 second $\left(\mathrm{FEV}_{1}\right)$, and force vital capacity (FVC) in both groups. No significant differences were found between the groups, characterizing the homogeneity of the sample.

Regarding cardiopulmonary variables (HR, SBP, DBP), $\mathrm{SpO}_{2}$, sensation of dyspnea and blood lactate pre-and posttreatment, for both the PT and the PT+B group, there was a significant increase of $\mathrm{SpO}_{2}(85 \% \pm 8 \%$ to $89 \% \pm 8 \%$ and $81 \% \pm 4 \%$ to $87 \% \pm 4 \%$; respectively) and decrease of dyspnea $(4.2 \pm 2.1$ to $1.4 \pm 1.4$ and $4.0 \pm 1.5$ to $1.5 \pm 1.8$, respectively) (Table 2). However, the HR (110.7 \pm 15.2 to $103.7 \pm 11.5 \mathrm{bpm}), \operatorname{SBP}(164.4 \pm 22.9$ to $140.0 \pm 21.9 \mathrm{~mm}$ $\mathrm{Hg})$, and blood lactate $(1.7 \pm 0.7$ to $1.3 \pm 0.7 \mathrm{mMol} / \mathrm{L})$ were

Table 1 - Anthropometric and pulmonary function tests of the study population in the physical training (PT) alone or associated with BiPAP (BT+B) groups

\begin{tabular}{|c|c|c|c|}
\hline VARIABLES & PT & $\mathrm{PT}+\mathrm{B}$ & Mann-Whitney \\
\hline Age (years) & $67.6 \pm 8.5$ & $66.8 \pm 10.6$ & Not significant \\
\hline Weight (kg) & $72.2 \pm 16.1$ & $71.4 \pm 10.7$ & Not significant \\
\hline Height (m) & $1.6 \pm 0.1$ & $1.6 \pm 0.06$ & Not significant \\
\hline Body Mass Index $\left(\mathrm{kg} / \mathrm{m}^{2}\right)$ & $27.3 \pm 6.0$ & $26.4 \pm 4.4$ & Not significant \\
\hline Vital Capacity (L) & $2.0 \pm 0.6$ & $2.0 \pm 0.7$ & Not significant \\
\hline Vital Capacity (\%) & $58 \pm 11$ & $60 \pm 21$ & Not significant \\
\hline Forced Vital Capacity (L) & $1.8 \pm 0.4$ & $1.9 \pm 0.7$ & Not significant \\
\hline Forced Vital Capacity (\%) & $55 \pm 11$ & $63 \pm 18$ & Not significant \\
\hline Forced expiratory volume in 1 second (L) & $0.8 \pm 0.2$ & $0.7 \pm 0.3$ & Not significant \\
\hline Forced expiratory volume in 1 second (\%) & $34 \pm 8$ & $33 \pm 10$ & Not significant \\
\hline Forced expiratory volume in 1 second/ Forced Vital Capacity (\%) & $48 \pm 9$ & $41 \pm 17$ & Not significant \\
\hline
\end{tabular}


significantly reduced only for the $\mathrm{PT}+\mathrm{B}$ group. In the posttreatment evaluation, lower values of blood lactate were obtained in the PT+B group when compared PT alone (2.5 \pm 0.9 versus $1.3 \pm 0.7 \mathrm{mMol} / \mathrm{L}$ ). Neither of the groups studied presented any significant alterations for DBP.

Regarding values for peak physical exercise, the intra- and intergroup analysis did not reveal significant alterations in vari- ables for $\mathrm{HR}$, SBP, DBP, $\mathrm{SpO}_{2}$, sensation of dyspnea, blood lactates, or $\mathrm{VCO}_{2}$ (Table 3). However, intragroup analysis revealed a significant increase in $\mathrm{VO}_{2}$ only in the $\mathrm{PT}+\mathrm{B}$ group $(0.9 \pm 0.3$ to $1.3 \pm 0.3 \mathrm{~L} / \mathrm{min})$. A significant increase in respiratory muscle strength was found for both groups (Figure 1).

Regarding the walking distance in CPT, a statistically significant increase occurred in both groups (Figure 2).

Table 2 - Results obtained at identical exercise levels during cardiopulmonary physical testing in the 2 groups

\begin{tabular}{|c|c|c|c|c|}
\hline & $\begin{array}{l}\text { PT } \\
\text { PRE }\end{array}$ & POST & $\begin{array}{l}\text { PT+B } \\
\text { PRE }\end{array}$ & POST \\
\hline Speed $(\mathrm{km} / \mathrm{h})$ & $2.6 \pm 0.9$ & $2.6 \pm 0.9$ & $2.8 \pm 0.6$ & $2.8 \pm 0.6$ \\
\hline Peripheral Oxygen Saturation (\%) & $85 \pm 8$ & $89 \pm 8^{*}$ & $81 \pm 4$ & $87 \pm 4^{*}$ \\
\hline Heart Rate (bpm) & $119.4 \pm 8.9$ & $114.1 \pm 11.4$ & $110.7 \pm 15.2$ & $103.7 \pm 11.5^{*}$ \\
\hline Systolic Blood Pressure (mm Hg) & $151.6 \pm 22.9$ & $138.8 \pm 9.2$ & $164.4 \pm 22.9$ & $140.0 \pm 21.9^{*}$ \\
\hline Diastolic Blood Pressure ( $\mathrm{mm} \mathrm{Hg}$ ) & $88.8 \pm 16.9$ & $84.4 \pm 14.2$ & $86.6 \pm 7.0$ & $84.4 \pm 10.1$ \\
\hline Dyspnea (Borg) & $4.2 \pm 2.1$ & $1.4 \pm 1.4^{*}$ & $4.0 \pm 1.5$ & $1.5 \pm 1.8^{*}$ \\
\hline Blood Lactate (mMol/L) & $2.0 \pm 1.0$ & $2.5 \pm 0.9$ & $1.7 \pm 0.7$ & $1.3 \pm 0.7 * \dagger$ \\
\hline
\end{tabular}

*Significantly different from pre-training. $P$ d" 0.05 . $†$ Significantly different between groups. $P$ d" 0.05 .

Table 3 - Results obtained at peak exercise during cardiopulmonary physical testing in the 2 groups

\begin{tabular}{lllll}
\hline & PT & & PT+B & \\
& PRE & POST & PRE & POST \\
\hline Speed $(\mathrm{km} / \mathrm{h})$ & $2.6 \pm 0.9$ & $4.1 \pm 1^{*}$ & $2.8 \pm 0.6$ & $4.1 \pm 1^{*}$ \\
Peripheral Oxygen Saturation peak $(\%)$ & $85 \pm 8$ & $85 \pm 8$ & $81 \pm 4$ & $82 \pm 5$ \\
Heart Rate peak (bpm) & $119.4 \pm 8.9$ & $131.5 \pm 17.2$ & $110.7 \pm 15.2$ & $117 \pm 10.8$ \\
Systolic Blood Pressure peak (mm Hg) & $151.6 \pm 22.9$ & $152.7 \pm 12.5$ & $164.4 \pm 22.9$ & $160 \pm 24.5$ \\
Diastolic Blood Pressure peak (mm Hg) & $88.8 \pm 16.9$ & $88.3 \pm 14.5$ & $86.6 \pm 7.0$ & $89.4 \pm 8.8$ \\
Dyspnea peak (Borg) & $4.0 \pm 2.1$ & $2.5 \pm 1.5$ & $4.0 \pm 1.5$ & $3.3 \pm 2.0$ \\
Lactate peak (mMol/L) & $2.0 \pm 1.0$ & $2.9 \pm 1.0$ & $1.7 \pm 0.7$ & $1.8 \pm 0.8$ \\
Oxygen Consumption peak (L/min) & $0.8 \pm 0.1$ & $1.1 \pm 0.5$ & $0.9 \pm 0.3$ & $1.3 \pm 0.3^{*}$ \\
Carbonic Gas Production peak (L/min) & $0.7 \pm 0.1$ & $1.0 \pm 0.5$ & $0.9 \pm 0.2$ & $1.1 \pm 0.3$ \\
\hline
\end{tabular}

*Significantly different from pretraining. $P$ d" 0.05 .

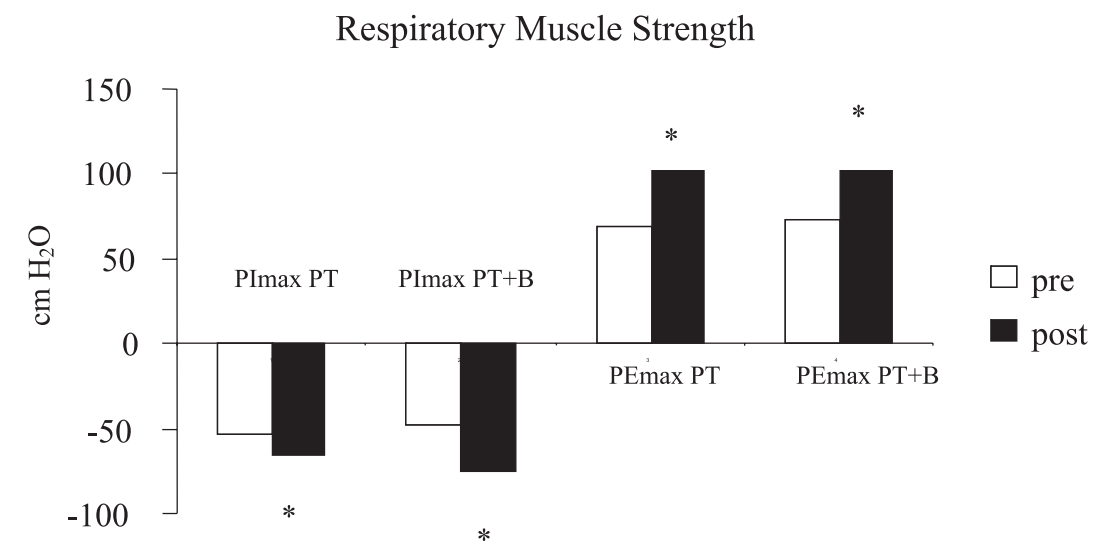

PImax PT: maximum inspiratory pressure in group performing physical training alone.

PEmax PT: maximum expiratory pressure in group performing physical training alone.

PImax PT+B: maximum inspiratory pressure in group undergoing physical training associated with the use of noninvasive ventilation.

PEmax PT+B: maximum expiratory pressure in group undergoing physical training associated with the use of noninvasive ventilation.

Figure 1 - Effect of physical training associated or not with the use of noninvasive ventilation on maximum expiratory and inspiratory pressure 


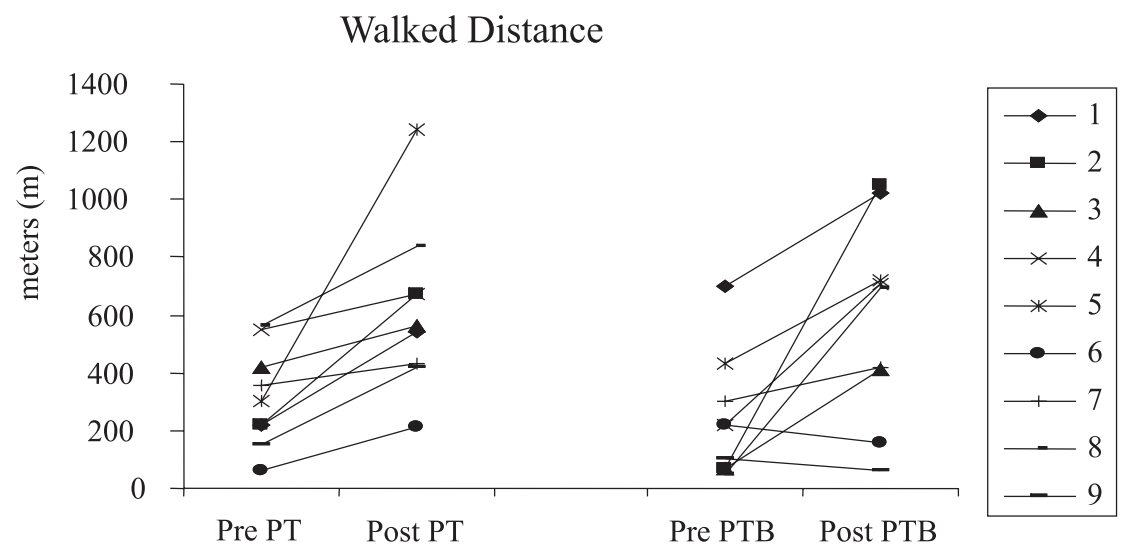

Pre PT: preintervention distance traveled for group undergoing physical training alone.

Post PT: postintervention distance traveled for group undergoing physical training alone.

Pre PTB: preintervention distance traveled for group undergoing physical training associated with the use of non invasive ventilation.

Post PTB: postintervention distance traveled for group undergoing physical training associated with the use of non invasive ventilation.

Figure 2 - Effect of physical training associated or not with the use of noninvasive ventilation on walking distance, by individual participant

\section{DISCUSSION}

Our main findings in this study regarding intragroup analysis at identical levels of physical exercise in CPT were: 1) a significant increase of $\mathrm{SPO}_{2}$ and a decrease of the sensation of dyspnea in both groups; 2) significant reductions of HR, SBP, and blood lactate only in the PT+B group; and 3) a significant reduction of blood lactate in the $\mathrm{PT}+\mathrm{B}$ group when compared to PT alone. Regarding the peak values in CPT, the intragroup analysis showed a significant increase in oxygen consumption only for the $\mathrm{PT}+\mathrm{B}$ group.

In our study, both the group undergoing PT alone and the group undergoing $\mathrm{PT}+\mathrm{BiPAP}^{\circledast}$ presented significant improvements in $\mathrm{SpO}_{2}$, sensation of dyspnea, respiratory muscle strength, and the distance walked in CPT. The results of the present study are in accordance with those obtained by other authors, ${ }^{11,25,26}$ who observed an increase in respiratory muscle strength, improvement in physical capacity, and a reduction in dyspnea in patients with COPD undergoing PT.

Physical exercise has been described as having an essential role in the rehabilitation of patients with COPD. Dyspnea leads to progressive physical deconditioning, causing losses in strength and peripheral muscle endurance, in addition to metabolic and gas exchange abnormalities. Regarding the period of physical training, reported studies show that PT programs produce physiological effects in these patients after a minimum of 6 to 8 weeks. Some ${ }^{12}$ show that this 6 to 8 week period may be relatively short for producing physiological adaptations. For this reason, we opted for a training period of 12 weeks, with the objective of evaluating whether the training period could also be an additional factor influencing the results obtained between groups.

Our results agree with a number of reports showing that NIV can produce additional effects during exercise in patients with COPD. Keilty ${ }^{27}$ observed a significant improvement in dyspnea symptoms during a submaximal test with the application of pressure support in patients with COPD. Other studies, which have investigated the role of NIV associated with physical training, have also shown beneficial effects, such as better exercise tolerance, ${ }^{18,28,29}$ a reduction in dyspnea, ${ }^{18}$ an increase in arterial oxygenation, ${ }^{28}$ and an increase in respiratory muscle strength. . $^{17,30,31}$

In this study, we found that only the group that underwent PT with BiPAP $^{\circledR}$ ventilation support had a significant reduction in SBP, HR, and blood lactate at the same intensity of exercise. The attenuation of these cardiovascular responses can be explained by the increase in muscular oxidation capacity, slowing the cardiovascular adjustments through metaboreflex response. Costes et $\mathrm{al}^{18}{ }^{18}$ in associating PT with NIV, observed a significant increase in oxygen consumption, but they found that there was no significant difference in blood lactate among the patients studied.

The use of NIV associated with physical exercise has been a useful option in patients with COPD and greater ventilatory limitation during physical exercise because it is a method that can offer respiratory assistance. In our patients with COPD, the use of BiPAP $^{\circledR}$ associated with PT on a treadmill significantly reduced the blood lactate, at 
the same exercise intensity as the CPT exercise. Regarding blood lactate, our results are in agreement with the studies by Borghi-Silva ${ }^{13}$ and Pires Di Lorenzo et al, ${ }^{32}$ who, studied patients with a greater degree of obstruction and observed a significant reduction of blood lactate only in the group that performed physical training associated with bi-level NIV. These results can be explained by the improvement in the oxidative muscle capacity due to the greater availability of oxygen to the tissue; even though we did not observe differences between groups for $\mathrm{SpO}_{2}$, the $\mathrm{PT}+\mathrm{B}$ group presented lower pretreatment base values; that is, they were more hypoxemic.

The benefits of the use of $\mathrm{BiPAP}^{\circledR}$ associated with physical exercise can probably be accounted for by the reduction of work for the diaphragm muscle, given the dynamic coupling of neuroventilation and the reduction of hyperinsuflation during physical effort. Aside from this, in diversion of blood flow from the peripheral muscle to the ventilatory muscle limits the continuity of physical exercise. ${ }^{33}$ It is possible that NIV can diminish mid-intrathoracic pressure and improve cardiac output, which could result in attenuation of the response of cardiovascular vari- ables and in a lower production of blood lactate when this intervention is associated with PT on a treadmill. These results were concomitantly obtained with the increase of oxygen consumption at peak exercise.

A first limitation of this study is the small number of patients studied, given the strict criteria for inclusion in this study. Another limitation was the impossibility of obtaining breath-to-breath ventilatory and metabolic data because the equipment evaluated these variables in averages of 20 seconds. In addition, it was not possible to evaluate the flow limitation and dynamic hyperinflation during exercise, which would have supplied an important evaluation of the noninvasive ventilation during the physical exercise. Despite these limitations, differences between the interventions studied can be observed with the methodology applied in this study.

Finally, we conclude that physical training associated with the application of 2 levels of pressure in the airways provided an improved aerobic capacity in our patients, and this adjunct therapy can be a useful recourse during physical rehabilitation of patients with COPD who present a moderate-to-severe COPD and dyspnea in response to effort.

\section{RESUMO}

A. Toledo, A. Borghi-Silva, L.M.M. Sampaio, Ribeiro K.P, V. Baldissera, D. Costa. O impacto da ventilação nãoinvasiva no treinamento físico em pacientes com doença pulmonar obstrutiva crônica moderada a grave. Clinics. 2007;62(2):113-20.

OBJETIVO: Avaliar a influência do treinamento físico, com e sem ventilação não invasiva com dois níveis de pressão nas vias aéreas (BiPAP $\left.{ }^{\circledR}\right)$, em pacientes com doença pulmonar obstrutiva crônica.

MÉTODOS: Dezoito pacientes com $\mathrm{VEF}_{1}=34 \pm 8 \%$ do previsto, idade média de $68 \pm 9$ anos, foram randomicamente distribuídos em dois grupos, um grupo realizando treinamento físico em esteira e outro grupo realizando treinamento físico associado ao $\mathrm{BiPAP}^{\circledR}$ (treinamento físico+B), durante 30 minutos, 3 vezes por semana, por 12 semanas. A velocidade do treinamento foi baseada no teste cardiopulmonar realizado pré e pós-intervenção, com registro dos valores de frequiência cardíaca, pressão arterial sistólica, pressão arterial diastólica, saturação periférica de oxigênio, lactato sanguíneo, sensação de dispnéia, força muscular respiratória e análise de gases expirados como consumo de oxigênio, produção de dióxido de carbono.

RESULTADOS: Em ambos os grupos houve melhora significativa na dispnéia e saturação periférica de oxigênio no mesmo nível de esforço, na distância percorrida no teste 
cardiopulmonar e na força muscular respiratória $(\mathrm{p}<0,05)$. Somente o grupo treinamento físico+B teve melhora significativa de frequiência cardíaca, pressão arterial sistólica e consumo de oxigênio após treinamento $(p<0,05)$. Além disso, significativa redução do lactato sanguíneo foi observada para o mesmo nível de exercício no grupo treinamento físico+B quando comparado com treinamento físico isolado $(1,3 \pm 0,7$ e $2,5 \pm 0,9 \mathrm{mMol} / \mathrm{L}, \mathrm{p}<0,05$, respectivamente).
CONCLUSÃO: O treinamento físico associado com BiPAP $^{\circledR}$ aumenta a capacidade muscular oxidativa, e pode ser um recurso coadjuvante da reabilitação física de pacientes com doença pulmonar obstrutiva crônica.

UNITERMOS: Doença pulmonar obstrutiva crônica (DPOC). Treinamento físico. BiPAP ${ }^{\circledR}$. Ventilação não invasiva. Teste cardiopulmonar.

\section{REFERENCES}

1. O’Donnel D. Ventilatory limitations in chronic obstructive pulmonary disease. Med Sci Sports Exerc. 2001;33:647-55.

2. Rodrigues SL, Silva CAM. Educação na Reabilitação Pulmonar. Reabilitação Pulmonar: conceitos básicos. São Paulo: Ed. Manole, cap.8, 2003, p.85-89.

3. Sturdy G, Hillman D, Gren D, Jenkins S, Cecins N, Eastwood P Feasibility of high-intensity, interval based respiratory muscle training in COPD. Chest. 2003;123:142-50

4. Barbara JA, Roca J, Ramirez J. Gas exchange during exercise in mild chronic obstructive pulmonary disease. Am Rev Respir Dis. 1991;144:520-5.

5. Dantzker DR, D'Alonzo GE. The effect of exercise on pulmonary gas exchange in patients with severe chronic obstructive pulmonary disease. Am Rev Respir Dis. 1986;134:1135-9.

6. Sarmiento R, Orozco-Levi M, Guell R, Barreiro E, Hernandez N, Mota $\mathrm{S}$, et al. Inspiratory muscle training in patients with chronic obstructive pulmonary disease: structural adaptation and physiologic outcomes. Am J Respir Crit Care Med. 2002;166:1491-7.

7. Casaburi R, Porszasz J, Burns MR, Carithers ER, Chang RSY, Cooper $\mathrm{CB}$. Physiologic benefits of exercise training in rehabilitation of patients with severe COPD. Am J Respir Crit Care Med. 1997;155:1541-51.

8. Casaburi R, Petty TL. Principles and practice of pulmonary rehabilitation. 1st ed, WB Sauders, Philadelphia, 1993.

9. Cooper CB. Exercise in chronic obstructive pulmonary disease: aerobic exercise prescription. Med Sci Sports Exerc. 2001;337:S671-9.

10. MCardle WD, Katch FL, Katch VL. Fisiologia do exercicio, energia, nutrição e desempenho humano. $3^{\mathrm{a}}$ edição, Guanabara Koogan S/A, Rio de Janeiro, 1992.

11. Neder JA, Nery LE, Cendon SPF, Ferreira IM, Jardim JRB. Reabilitação Pulmonar: fatores relacionados ao ganho aeróbio de pacientes com COPD. Jornal de Pneumologia, 1997;233:115-23.

12. Bourjeily G, Rochester CL. Exercise training in chronic obstructive pulmonary disease. Clin Chest Med. 2000;21:763-81.
13. Borghi-Silva A. Efeitos do treinamento fisico associado ao BiPAP $^{\circledR}$ sobre as respostas cardiorrespiratórias, força, endurance muscular e qualidade de vida em pacientes com COPD. Doctoral thesis, Departamento de Fisioterapia Respiratória, Universidade Federal de São Carlos, São Carlos, SP, Brazil, 2004.

14. Brochard L. Non invasive ventilation for acute exacerbations on COPD: a new standard of care. Thorax, 2000;55:817-8.

15. Brochard L, Mancebo J, Wysocki M, Lofaso F, Conti G., Rauss A, et al. Noninvasive ventilation for acute exacerbations of chronic obstructive pulmonary disease. N Engl J Med. 1995; v.333, p. 817-822.

16. Janssens JP. Management of dyspneia in severe COPD. Journal of Pain and Symptom Management, 2000;19(:378-92.

17. Vanpee D, Khawand CE, Rousseau L, Jamart J, Delaunois L. Effects of nasal pressure support on ventilation and inspiratory work in normocapnic and hypercapnic patients with COPD. Chest, 2002;122:7583.

18. Costes F, Agresti A, Court-Fortune I, Roche F, Vergnon JM, Barthelemy JC. Noninvasive ventilation during exercise training improves exercise tolerance in patients with chronic obstructive pulmonary disease. J Cardiopulm Rehabil. 2003;23:307-13.

19. Bianchi L, Foglio K, Porta R, Baiardi P, Vitacca M, Ambrosino N. Lack of additional effect of adjunct of assisted ventilation to pulmonary rehabilitation in mild COPD patients. Respiratory Medicine. 2002;96:359-67.

20. American Thoracic Society. Standardization of spirometry. Am Rev Respir Dis. 1987;136:1285-99.

21. Knudson RJ, Leibowitz MD, Holberg Cj, Burrows B. Changes in the normal maximal expiratory flow-volume curve growth and aging. Am Rev Respir Dis. 1983;127:725-34.

22. Black LF, Hyatt RE. Maximal respiratory pressures: normal values and relationship to age and sex. Am Rev Respir Dis. 1969;99:696-702.

23. Diretrizes para testes de função pulmonar. Jornal de Pneumologia, 2002;28:221-31. 
24. Borg GA. Psychophysical bases of perceived exertion. Med Sci Sports Exerc. 1982;14:377-81.

25. Ries AL, Kaplan RM, Limberg TM, Prewitt LM. Effects of pulmonary rehabilitation on physiologic and psychosocial outcomes in patients with obstructive pulmonary disease. Annals of Internal Medicine, 1995; 122:823-32.

26. Paulin E, Brunetto AF, Carvalho CRF. Effects of a physical exercises program designed to increase thoracic mobility in patients with chronic obstructive pulmonary disease. Jornal de Pneumologia, 2003;29:28794.

27. Keilty SE. Effect of inspiratory pressure support on exercise tolerance and breathlessness in patients with severe stable chronic obstructive pulmonary disease. Thorax. 1994;49:990-4.

28. Garrod R, Mikelsons C, Paul EA, Wedzicha JA. Randomized controlled trial of domiciliary noninvasive positive pressure ventilation and physical training in severe chronic obstructive pulmonary disease. Am J Respir Crit Care Med. 2000;162:1335-41.
29. Hawkins P, Johnson LC, Nikoletou D, Hamnegard, C-H, Sherwood R, Polkey MI, et al. Proportional assist ventilation as an aid to exercise training in severe chronic obstructive pulmonary disease. Thorax. 2002; 57:853-9.

30. Vitacca M, Nava S, Confalionieri M. The appropriate setting of noninvasive pressure support ventilation in stable COPD patients. Am Rev Respir Dis. 2000;118:1286-93.

31. Wijkstra PJ, Lacasse Y, Gordon H, Casanova C, Gay PC, Jones JM, et al. A meta-analysis of nocturnal noninvasive positive pressure ventilation in patients with stable CPOD. Chest. 2003;124:337-43.

32. Pires Di Lorenzo VA, Silva AB, Sampaio LLM, Jamami M, Oishi J, Costa D. Efeitos do treinamento fisico e muscular respiratório em pacientes com COPD grave submetidos ao BiPAP ${ }^{\circledR}$. Revista Brasileira de Fisioterapia. 2003;7:69-76.

33. Aliverti A, Macklem PT. How and why exercise is impaired in COPD Respiration. 2001;68:229-39. 